\title{
Application of Constructed Wetlands for the Nitrogen Removal LU Xu-jie*
}

School of Chemical and Environmental Engineering, Jianghan University, China

Nitrogen was a main contaminant of surface water in China presently. For instance, discharges of oil refining, chemical fertilizer, food and cultivation industry production have high concentration ammonia nitrogen in China, and the concentration of ammonia nitrogen is $200-6000 \mathrm{mg} / \mathrm{L}$ [1]. Uncontrolled discharge of nitrogen into natural water channels stimulates eutrophication of surface waters, such as lakes and rivers $[1,2]$. Thus, contamination of water bodies by nitrogen has led to increasing attention focused on wastewater treatment. As well, Nitrogen removal urgently needed to be solved as one of the difficult problem in the current wastewater treatment. At present, more and more researchers focused on simple and low-cost natural technologies (e.g constructed wetlands). As typical natural and environmental friendly systems $[3,4]$ constructed wetlands primarily depend on naturally occurring energies such as solar radiation, and biomass storage, and using rooted water tolerant plants and media to provide treatment of wastewater [5,6]. As a green treatment technology and engineering measure, they have the unique advantage of producing higher effluent quality without the input of fossil energy thereby reducing operation costs and high costs of the maintenance [7-10]. Constructed wetlands are engineered wetlands with saturated or unsaturated substrates, a large biomass of plants, such as emergent, floating and submergent, and a large variety of microbial communities, like the as nitrifying bacteria denitrifying bacteria [6]. Compare with conventional technologies (such as membrane bioreactors), constructed wetlands have higher nitrogen removal efficiency and lower organic removal by increasing the contact time between wastewater and biofilms [11,12]. Besides, the characteristics of constructed wetlands are impacting resistance, stabilizing the effluent quality, simplifying operation and maintenance, and low operating cost. However, their floor spaces are larger, and the wetlands exhibit higher pollutant removal rates under greater loadings conditions [1]. In extremely cold areas, the phenomenon is more significant. The wastewater treatment technology of constructed wetlands is increasable widely used in urban and rural areas of South China [13-16]. However, constructed wetlands were not widespread uses of technology in China which spans 49 latitudes, resulting in the large differences in climate, terrain and plant communities between South and North China, especially low temperature under winter cold climate condition, such as in Northeast China. Hence, there are a lot of difficulties in adopting constructed wetlands in Northeast China.

Nitrogen was mainly removed by media adsorption, plant uptake and microbial activities in constructed wetland systems. Porous media provides attachment surfaces for plants and microbial communities and ingredients for bio-reactions as well as removing nitrogen by sedimentation, filtration and adsorption of media. However, porous media can not provide long-term stable the capacity of nitrogen removal due to their saturated adsorption, resulting in releasing nitrogen from media. Besides, nitrogen removal was no obvious by plant uptake with the low absorbing capacity [17]. As well, most plants are dormant and wilting during the cold winter in Northeast China, and have no capacity for absorbing nitrogen, which lead to reduce the nitrogen mitigation capacity of constructed wetlands. Most studies reported that nitrification and denitrification of microbes was a mainly method of nitrogen removal in constructed wetlands [18-21]. Temperature and dissolved oxygen (DO) play an important role in nitrification and denitrification of microbes in constructed wetlands [22]. Too high or low temperatures will restrain nitrification and denitrification of microbes $[6,21,23,24]$. The optimum temperature of nitrification and denitrification are $20-25^{\circ} \mathrm{C}$, and there were hardly nitrogen removal at about $6^{\circ} \mathrm{C}$, though construction wetlands were normally run during harsh winter $\left(-25^{\circ} \mathrm{C}\right)$, the temperature occurred by accident and was not long-term $[25,26]$. The wetlands did not easily operated in Northeast China due to lower temperature $\left(<-30^{\circ} \mathrm{C}\right)$ [27]. Even if the temperature of construction wetlands is improved by isolation measures, the values of the temperature are still very low $\left(0-5^{\circ} \mathrm{C}\right)$ [28]. In winter there is great dusty permafrost in Northeast China. Permafrost forms easily in the surface of construction wetlands under low temperature, which results in restricting nitrogen removal. Xiang et al. (2009) found that wetland systems freezes and blocks easily as well as water conduit system and water outlet under winter running conditions, leading to poor drainage [29]. In addition, plants have no ability of transporting oxygen because of dried-up plant tissues in winter in the areas. Hence, some researchers thought that construction wetlands do not suit to apply in Northeast China in winter due to longer frozen (>125 d) [30]. However, we think that reformatory constructed wetlands would be used in Northeast China during the winter.

Carbon source is not only in favour of microbial denitrification but also use the carbonaceous material to synthesis their cells, while amount of carbon decrease under low temperature due to the high removal rate of biochemical oxygen demand (BOD) [31,32]. In order to increase the denitrification rate, sufficient carbon source should be added in the period, and the wetlands should be operated with the intermittent strategy so as to improve the capacity of oxygen transfer and increase amount of dissolved oxygen (DO) in the system [33,34]. Artificial aeration should not be overlooked as well. However, the increase of DO can enhance the nitrification reaction rate and the growth rate of the nitrifying bacteria, but inhibit the denitrifying bacteria activities, which go against nitrogen removal. Thus, a certain quantity of DO is necessary. Screening microbes which have the ability of nitrification and de nitrification can live by making full use of nitrogen under low temperature in winter [35]. Strengthening isolation measures of construction wetlands attracts researchers' attention so as to expand the range of their application, especially in extremely cold areas, such as a small greenhouse, plastic mulching and insulation materials. Nivala et al. [36] found that upon the installation of a pretreatment chamber and a aeration system, treatment efficiencies of the constructed wetlands dramatically improved at the Jones County Municipal Landfill near Anamosa, Iowa in winder. Under the same permafrost condition, the depth of constructed wetlands increase in order to insulate the cold air, and hydraulic retention time (HRT) are prolonged by adjusting the flow velocity of influent and effluent. Christos et al. [37] found

*Corresponding author: LU Xu-jie, School of Chemical and Environmenta Engineering, Jianghan University, China, E-mail: xujie_lu@163.com

Received December 07, 2012; Accepted December 08, 2012; Published December 18, 2012

Citation: Xu-jie LU (2013) Application of Constructed Wetlands for the Nitrogen Removal. J Civil Environ Eng 3: e108. doi:10.4172/2165-784X.1000e108

Copyright: () 2013 Xu-jie LU. This is an open-access article distributed under the terms of the Creative Commons Attribution License, which permits unrestricted use, distribution, and reproduction in any medium, provided the original author and source are credited. 
that HRT were about $6 \mathrm{~d}$ in winter when constructed wetlands have high ability of pollutant removal. However, the studies of constructed wetlands are still in a preliminary stage in the cold area of China, especially in Northeast China. As a result, there are some shortages on optimization measures of the wetland systems, such as the sources and using conditions of insulation material, appropriate HRT, and the suitable habitat of microbes due to the differences of climate and regions.

Hence, people should adjust measures to local conditions and comprehensive evaluation for constructed wetlands, especially in extremely cold areas. And we should cut down the treatment difficulties and cost of the wastewater of high initial nutrient concentrations, and combine other treatment technologies in the areas, such as biological chemical water treatment. Both physicochemical and biological methods should be used for nitrogen removal in constructed wetlands. It is necessary to study hybrid constructed wetlands with some different types in Northeast China.

\section{References}

1. Song X, Li Q, Yan D (2010) Nutrient removal by hybrid subsurface flow constructed wetlands for high concentration ammonia nitrogen wastewater. Procedia Environmental Sciences 2: 1461-1468.

2. Chen Y, Wen Y, Cheng J, Xue C, Yang D, et al. (2011) Effects of dissolved oxygen on extracellular enzymes activities and transformation of carbon sources from plant biomass: implications for denitrification in constructed wetlands. Bioresour Technol 102: 2433-2440.

3. Cooper $P$ (2009) What can we learn from old wetlands? Lessons that have been learned and some that may have been forgotten over the past 20 years. Desalination 246: 11-26.

4. Dan TH, Quang LN, Chiem NH, Brix H (2011) Treatment of high-strength wastewater in tropical constructed wetlands planted with Sesbania sesban: horizontal subsurface flow versus vertical downflow. Ecol Eng 37: 711-720.

5. Kadlec RH, Knight RL (1996) Treatment Wetlands. CRC Press LLC, Boca Raton, FL 33431, USA

6. Saeed T, Sun G (2012) A review on nitrogen and organics removal mechanisms in subsurface flow constructed wetlands: Dependency on environmental parameters, operating conditions and supporting media. J Environ Manage 112: 429-448.

7. Sim CH, Yusoff MK, Shutes B, Ho SC, Mansor M (2008) Nutrient removal in a pilot and full scale constructed wetland, Putrajaya city, Malaysia. J Environ Manage 88: 307-317.

8. Contreras JAV, Gerba CP, Fuentes HR (2010) Dispersion Number and PRD1 Recovery in Constructed Wetlands. In: Proceedings of 12th International Conference on Wetland Systems for Water Pollution Control, vol. II, October, San Servolo Island, Venice, Italy.

9. Lee S, Maniquiz MC, Kim LH (2010) Characteristics of contaminants in water and sediment of a constructed wetland treating piggery wastewater effluent. J Environ Sci 22: 940-945

10. Bruch I, Fritsche J, Bänninger D, Alewella U, Sendelov M, et al. (2011) Improving the treatment efficiency of constructed wetlands with zeolite-containing filte sands. Bioresour Technol 102: 937-941.

11. Sakadevan K, Bavor HJ (1999) Nutrient removal mechanisms in constructed wetlands and sustainable water management. Water Sci Technol 40: 121-128.

12. Trang NTD, Konnerup D, Schierup HH, Chiem NH, Tuan LA, et al. (2010) Kinetics of pollutant removal from domestic wastewater in a tropical horizontal subsurface flow constructed wetland system: effects of hydraulic loading rate. Ecological Engineering 36: 527-535

13. Fan X, Cui B, Zhang K, Zhang Z, Zhao H (2012) Construction of River Channelwetland Networks for Controlling Water Pollution in the Pearl River Delta, China. Clean - Soil, Air, Water 40: 1027-1035.

14. Liu X, Huang SL, Tang TFZ, Liu XG, Scholz M (2012) Growth characteristics and nutrient removal capability of plants in subsurface vertical flow constructed wetlands. Ecol Eng 44: 189-198.

15. Yu R, Wu Q, Lu X (2012) Constructed Wetland in a Compact Rural Domestic
Wastewater Treatment System for Nutrient Removal. Environmental Engineering Science 29: 751-757.

16. Zhang T, Xu D, He F, Zhang YY, Wu ZB (2012) Application of constructed wetland for water pollution control in China during 1990-2010. Ecol Eng 47: 189-197.

17. Brix H (1997) Do macrophytes play a role in constructed treatment wetlands? Water Sci Technol 35: 11-17.

18. Ding Yi, Song X, Wang Y, Yan D (2012) Effects of dissolved oxygen and influent $\mathrm{COD} / \mathrm{N}$ ratios on nitrogen removal in horizontal subsurface flow constructed wetland. Ecol Eng 46: 107-111.

19. He Y, Tao W, Wang Z, Shayya W (2012) Effects of pH and seasonal temperature variation on simultaneous partial nitrification and anammox in freewater surface wetlands. J Environ Manage 110: 103-109.

20. Mallin MA, McAuliffe JA, Mclver MR, Mayes D, Hanson MA (2012) High pollutant removal efficacy of a large constructed wetland leads to receiving stream improvements. J Environ Qual 41: 2046-2055.

21. Sun G, Zhu Y, Saeed T, Zhang G, Lu X (2012) Nitrogen removal and microbia community profiles in six wetland columns receiving high ammonia load. Chem Eng J 203: 326-332.

22. Garcia J, Rousseau DPL, Morato J, Lesage E, Matamoros V, et al. (2010) Contaminant removal process in subsurface-flow constructed wetlands: a review. Critical Reviews in Environmental Science and Technology 40: 561661.

23. Mæhlum $T$ (1998) Wetlands for treatment of landfill leachates in cold climates. In: Mulamoottil G, McBean EA, Rovers F (Eds.) Proceedings of the Constructed Wetlands for the Treatment of Landfi II Leachates, CRC Lewis Publishers, NY, USA.

24. Tao WD, He YL, Wang ZY, Smith R, Shayya W, et al. (2012) Effects of pH and temperature on coupling nitritation and anammox in biofilters treating dairy wastewater. Ecolo Eng 47: 76-82.

25. Herskowitz J, Black S, Sewandowski W (1987) Listowel artificial marsh treatment project. In: Reddy KR, Smith WH, (Eds.) Aquatic Plants for Water Treatment and Resource Recovery. Magnolia Publishing Co, Orlando, FL.

26. Wang HD, Miao Y, Song W, Wang G (2011) The applications of constructed wetland in wastewater treatments. Plant and Environment 11.

27. Wang Z, Wang JJ, Chen XD, Li J, Wang S (2009) Research Advance on Constructed Wetlands in Cold Region. Environmental Protection Science 35 30-33.

28. Liu XY, Dai ML, Liu PL (2004) Application of subsurface flow constructed wetland in north area of China in winter. Journal of Agro-Environment Science 23: 1077-1081.

29. Xiang XM, Yang HT, Zhou JT, Yang FL, Wang ZH (2009) Performance of Constructed Wetland for Municipal Wastewater Tertiary Treatment: Winter and Summer Comparison. Huan Jing Ke Xue 30: 713-719.

30. Xu YY, Yan BX, Zhu H, Luan Q (2012) Dewfall variation by large-scale reclamation in Sanjiang Plain. Wetlands 32: 783-790.

31. Knowles R (1982) Denitrification. Microbiol Rev 46: 43-70.

32. Werker AG, Dougherty JM, McHenry JL, Van Loon WA (2002) Treatment variability for wetland wastewater treatment design in cold climates. Ecol Eng 19: $1-11$.

33. Jia WL, Zhang J, Li PZ, Xie H, Wu J, et al. (2011) Nitrous oxide emissions from surface flow and subsurface flow constructed wetland microcosms: Effect of feeding strategies. Ecol Eng 37: 1815-1821.

34. Hu YS, Zhao Y, Zhao X, Kumar JL (2012) High Rate Nitrogen Removal in an Alum sludge-based intermittent aeration constructed wetland. Environ Sci Technol 46: 4583-4590.

35. Knoop S, Kunst S (1998) Influence of temperature and sludge loading on activated sludge settling, especially on Microthrix parvicella. Water Science and Technology 37: 27-35.

36. Nivala J, Hoos MB, Cross C, Wallace S, Parkin G (2007) Treatment of landfil leachate using an aerated, horizontal subsurface-flow constructed wetland. SSci Total Environ 380: 19-27.

37. Christos SA, Vassilios AT (2007) Effect of temperature, HRT, vegetation and porous media on removal efficiency of pilot-scale horizontal subsurface flow constructed wetlands. Ecol Eng 29: 68-73. 